\title{
Article
}

\section{Educational Quality Thresholds in the Diffusion of Knowledge with Mobile Phones for Inclusive Human Development in Sub-Saharan Africa}

Asongu, Simplice and Nwachukwu, Jacinta Chikaodi

Available at http://clok.uclan.ac.uk/25161/

Asongu, Simplice and Nwachukwu, Jacinta Chikaodi ORCID: 0000-0003-29879242 (2018) Educational Quality Thresholds in the Diffusion of Knowledge with Mobile Phones for Inclusive Human Development in Sub-Saharan Africa. Technological Forecasting and Social Change, 129 . pp. 164-172. ISSN 00401625

It is advisable to refer to the publisher's version if you intend to cite from the work. http://dx.doi.org/10.1016/j.techfore.2018.01.004

For more information about UCLan's research in this area go to http://www.uclan.ac.uk/researchgroups/ and search for <name of research Group>.

For information about Research generally at UCLan please go to http://www.uclan.ac.uk/research/

All outputs in CLoK are protected by Intellectual Property Rights law, including Copyright law. Copyright, IPR and Moral Rights for the works on this site are retained by the individual authors and/or other copyright owners. Terms and conditions for use of this material are defined in the policies page. 


\section{$\underline{\text { A G D I Working Paper }}$}

\section{$\mathrm{WP} / 17 / 057$}

\section{Educational Quality Thresholds in the Diffusion of Knowledge with Mobile Phones for Inclusive Human Development in Sub-Saharan Africa}

Forthcoming: Technological Forecasting and Social Change

\section{Simplice A. Asongu}

African Governance and Development Institute, P.O. Box 8413, Yaoundé, Cameroon.

E-mail: asongusimplice@yahoo.com /asongus@afridev.org

\section{Jacinta C. Nwachukwu}

School of Economics, Finance and Accounting, Faculty of Business and Law, Coventry University Priory Street,

Coventry, CV1 5FB, UK

Email: jacinta.nwachukwu@coventry.ac.uk 
Research Department

\title{
Educational Quality Thresholds in the Diffusion of Knowledge with Mobile Phones for Inclusive Human Development in Sub-Saharan Africa
}

\section{Simplice A. Asongu \& Jacinta C. Nwachukwu}

January 2017

\begin{abstract}
The study investigates critical masses or thresholds of educational quality at which the diffusion of information with mobile phones enhances inclusive human development. The empirical evidence is based on simultaneity-robust Fixed Effects regressions with data from 49 Sub-Saharan African countries for the period 2000-2012. The following findings are established: (1) There are positive marginal and net effects on inclusive development from the interaction between mobile phones and educational quality, (2) Between 10 and 27 pupils per teacher is needed in primary education in order for mobile phones to enhance inclusive human development, (3) From a comparative dimension: (i) English Common law countries enjoy higher net effects compared to their French Civil law counterparts, (ii) positive net effects are more obvious in politically stable (vis-à-vis politically unstable) countries, (iii) positive net impacts are also more apparent in resource-poor (vis-à-vis resource-rich) countries, (iv) low income (vis-à-vis higher income) countries have a higher net effect on inclusive development, (v) landlocked (vis-à-vis unlandlocked) countries experience higher net effects and (iv) Islam-dominated countries have a slightly higher net impact compared to their Christian-oriented counterparts.
\end{abstract}

JEL Classification: G20; I10; I32; O40; O55

Keywords: Mobile phones; inclusive human development; Africa 


\section{Introduction}

This study investigates thresholds of educational quality at which the diffusion of information with mobile phones improves inclusive human development in Sub-Saharan Africa (SSA). The academic and policy relevance of the inquiry are at least threefold, notably: (i) increasing levels of extreme poverty in the sub-region, (ii) the high potential for mobile phone penetration in Africa vis-à-vis other world regions and (iii) the growing relevance of a knowledge economy in $21^{\text {st }}$ century development.

First, extreme poverty levels are staggering in SSA because as a recent World Bank report on the attainment of Millennium Development Goals (MDGs) has shown, extreme poverty has been decreasing in all regions of the world with the exception of SSA where about 45 percent of countries in the sub-region have been experiencing increasing extreme poverty levels (World Bank, 2015; Asongu \& Kodila-Tedika, 2017) ${ }^{1}$.

Second, compared to other regions of the world, there is a great potential for mobile phone penetration in Africa ${ }^{2}$. According to Penard et al. (2012) and Asongu (2017a), whereas some emerging countries (e.g. in Latin America and Asia) and developed countries are experiencing stabilization in the penetration of information and communication technology (ICT), there is still a healthy room for leveraging mobile phones for development purposes in Africa. ICT has been established to contribute to inclusive and sustainable development (Alkemade \& Surrs, 2012).

Third, educational quality has been documented to be valuable at enhancing inclusive development in developing countries (Dakhi \& de Clereq, 2007; Dunlap-Hinkler et al., 2010). Beside the relevance of an excellent educational system in the post-2015 sustainable development agenda is centred on the 'knowledge economy'-driven policies. According to Tchamyou (2016), a knowledge economy is indispensable in addressing contemporary development challenges ${ }^{3}$.

\footnotetext{
${ }^{1}$ According to Ravallion et al. (2008), extreme poverty which was originally defined by the United Nations in 1995 is an economic condition that is characterized by substantial deprivation in basic human needs, notably: health, education, shelter, safe drinkable water, food and information. While in 2008 the international poverty line was 1.25US\$ per day (in 2005 prices), up from 1.00 US\$ per day in 1996; in 2017 it is 1.90 US\$ per day. The number of people living in extreme poverty has been increasing in Sub-Saharan Africa, probably because the benefits of over two decades of economic growth resurgence have not been distributed equitably across the population.

2 The terms, 'mobile phone penetration', 'mobile telephony', 'mobile' and 'mobile phones' are used interchangeably throughout this paper. It is important to note that "mobile phone" and "mobile telephony" respectively relate to hardware and service provision.

${ }^{3}$ Education, knowledge and access to accurate and timely information are also important to avoid the failure of investments in African business and development projects (Ika \& Saint-Macary, 2014; Hashim, 2014; Ofori, 2014; Joseph et al., 2014).
} 
This investigation incorporates the three strands above by using educational quality as a policy variable in the role of mobile phones for inclusive development. In theory, the above justifications are connected with the present inquiry because the educational quality and the growth potential of the mobile phone can be successfully harnessed to tackle the policy syndrome of non-inclusive development in SSA. Furthermore, there have been increasing requests for more research on the development outcomes of mobile phones, partly because caution has been expressed in scholarly circles for the mobile phone not to be considered as a silver bullet for development (Mpogole et al., 2008, p. 71).

The positioning of this paper contributes to the extant literature on the importance of mobile phones in inclusive human development. Most specifically, (i) empowerment of the female gender (Maurer, 2008; Ojo et al., 2012); (ii) improvement of health services for the underprivileged (Kliner et al., 2013); (iii) enhancement of financial inclusion (Singh, 2012; Kirui et al., 2013); (iv) reduction of the rural-urban poverty gap (Qiang et al., 2011; Chan \& Jia, 2011); (v) elimination of demand-supply divergences, (vi) wastes in agriculture and demand-/supply-side constraints (Muto \& Yamano, 2009; Aker \& Fafchamps, 2010); (vii) social change and development (Gupta \& Jain, 2014, 2015; Amankwah-Amoah, 2015, 2016; Amankwah-Amoah \& Sarpong, 2016; Afutu-Kotey et al., 2017); (viii) inequality adjusted human development (Asongu \& Le Roux, 2017); (ix) household management efficiency (Al Surikhi, 2012) and (x) consolidation of opportunities in business (Ondiege, 2010; Mishra \& Bisht, 2013; Asongu, 2015). Accordingly, in addition to facilitating the doing of business (Lee et al., 2010; Jin \& von Zedtwitz, 2008; Kuoa \& Yub, 2006; Kumar \& Zahn, 2003), the revolution in mobile phone usage has led to substantial positive externalities in inclusive human development.

This study extends the aforementioned stream of literature by investigating policy thresholds at which educational quality can complement mobile phones in order to promote inclusive human development in SSA. In other words, we seek to investigate the role of educational quality in modulating the effect of mobile phones on inclusive human development. Educational quality which is measured in terms of the number of pupils per qualified teacher in primary schools is an input variable. The notion of threshold represents the minimum requirements in educational excellence needed to achieve inclusive human development with mobile phones. In order to enhance the opportunity for policy implications, the analysis is further decomposed into fundamental characteristics of human development based on income levels (upper middle income, middle income versus low income); legal 
origins (English common law vs. and French civil law); religious domination (Christianoriented vs. Islam-dominated); openness to sea (landlocked vs. coastal); mineral resourcerich (petroleum vs. non-petroleum exporting); conflict (politically stable vs. unstable) countries.

By contributing to the macroeconomic literature on the management of technology for non-exclusive outcomes, this study steers clear of mainstream microeconomic and corporate technological innovation literature on the management of technology for business opportunities. To be sure, some of the categories in the bulk of corporate technological innovation literature have included: opportunity discovery and opportunity creation within the setting of disruptive innovation (Wan et al., 2015; Hang et al., 2015); governance for entrepreneurship (Asongu et al., 2017); identification of opportunities by scientific entrepreneurs (Maine et al., 2015); emerging ecosystems (Overholm, 2015); targeting of entrepreneurial innovators who are innovating continuously because of evolving financial resources and skills (Best, 2015); entrepreneurial avenues for the ageing (Kohlbacher et al., 2015) and innovation in technology for road-mapping new opportunities in patents (Jeong \& Yoon, 2015) $)^{4}$.

In the light of the above, this study complements the aspects of studies on distributional externalities (Cozzens, 2011). Within this framework, our study is closest to the growing stream of inquiries on the importance of mobile phones in social change and development outcomes (Mira \& Dangersfield, 2012; Brouwer \& Brito, 2012; Islama \& Meadeb, 2012). Whereas, the underlying literature has been documented on both developing (Gupta \& Jain, 2012; Sonne, 2012) and developed (Thakar, 2012) countries, the policy challenges are more apparent in developing countries, especially in SSA. This region is experiencing limited development outcomes, despite enjoying more than two decades of growth resurgence (Fosu, 2015a, p.44).

The rest of the study is structured as follows. Theoretical underpinnings are engaged in Section 2 while the data and empirical methodology are covered in Section 3. Section 4 presents and discusses the findings whereas Section 5 concludes with future research directions.

\footnotetext{
${ }^{4}$ This paragraph aims to position the study within the context of recent information technology and technology management literature.
} 


\section{Theoretical background}

\subsection{Innovation and growth}

Consistent with Asongu et al (2016), the relevance of ICT and knowledge in economic prosperity has long been documented in the management and economics literature. In general, these writers, acknowledged a two-way causality between economic activity and knowledge. Contrary to early neo-classical frameworks which conceived technology and knowledge as a kind of public commodity and exclusively exogenous to the economic system, novel models of economic prosperity are based on both neo-Schumpeterian and endogenous interpretations of economic development (Howells, 2005). In accordance with new models of growth, progress in technology is the result of direct investment and actions by people via the mobilization of fundamental resources associated with human capital (see Romer, 1990).

Within the above context, the theory of new growth considers technology in terms of a knowledge generation and private commodities which can be rewarded with intellectual property rights, as well as other forms of returns in innovation (Solow, 1994). Whereas the private characteristics of technology (e.g. monopolistic power and patents) have been confirmed in economic models, some scholars believe that monopolistic rents in technology are temporary and incomplete (Uzawa, 1965). The postulation that technological progress and innovation can both be endogenous and exogenous to an economic system has been supported by Romer (1990) who argued that certain features in technology predispose it to become a public commodity as time unfolds. According to Romer, because of cross-country spillovers in technology and innovation, countries experience heterogeneous benefits from innovations in technology. Hence, innovation could result in a disequilibrium in processes of human and economic developments, which explains cross-country variations in economic prosperity (Verspagen, 1997). This narrative accords with Rosenberg (1972) who earlier authenticated that the degree by which novel technologies are employed for productive processes are fundamental in explaining economic development. Therefore innovation outputs can be harnessed for inclusive development.

\subsection{Innovation outputs and inclusive development}

Innovation outputs represent important drivers of inclusive and sustainable development at corporate and national levels because they are influenced by a plethora of features which include human capital as well as the creation and diffusion of knowledge. A critical ingredient for innovation is human capital which according to Coleman (1998) can be 
defined as an individual's abilities, expertise, skills and knowledge that allow for variations in action and economic growth. According to Rosenberg (1972), human capital is a crucial basis for usage and fruitful exploitation of improved technology. With the help of formal and continuous training, it is possible for members within a society to constantly update their skills, capabilities and know-how (Dakhi \& de Clereq, 2007; Kwan \& Chiu, 2015). The duration of the learning period is contingent on a multitude of factors; including the complexity of the new technology as well as the educational level (Asongu \& Nwachukwu, 2017). In SSA that is characterised with a low literacy rate, the quality of education is essential to understand how the diffusion of technology is accommodated by existing knowledge.

Another critical angle of innovation output is the creation and diffusion of knowledge (see Kwan \& Chiu, 2015). According to neoclassical growth models, the transfer of technology is a fundamental source of innovation in developing countries (see Abramowitz, 1986; Bernard \& Jones, 1996; Becheikh, 2013; Kamukama, 2013; Makanyeza, \& Dzvuke, 2015; Tarus \& Sitienei, 2015; Tchamyou, 2016; Asongu, 2017b; Tchamyou \& Asongu, 2017). The dissemination of knowledge is a direct assessment of innovation output (Kwan \& Chiu, 2015). Reasonably, the creation and diffusion of knowledge include indicators like, among others, foreign direct investment (FDI); ICT and published journals of scientific and technical nature (see World Bank Knowledge Economy Index; Global Innovation Index, 2013) $)^{5}$. As argued by Asongu et al. (2016), while ideas are conceived in the minds of individuals, interactions (e.g. connectivity) among individuals are fundamental to the development of these ideas. In other words, the development and amplification of new knowledge is contingent on the interactions between individuals. It follows that the improvement in social and economic wellbeing within a nation depends on a plethora of interactions and features relating to human capital (Badinger \& Tondi, 2005; Asongu \& Nwachukwu, 2016b).

\section{Data and methodology}

\subsection{Data}

We assess the education thresholds in mobile phones for inclusive human development in a panel of forty nine African nations with data from the United Nations

\footnotetext{
${ }^{5}$ The Global Innovation Index is jointly published annually by Cornell University, INSEAD, and the World Intellectual Property Organisation.
} 
Development Program (UNDP) and African Development Indicators (ADI) of the World Bank for the period 2000-2012. This periodicity is motivated by data availability constraints. In line with recent African inclusive development literature, the outcome indicator is measured with the inequality adjusted human development index (IHDI) (Asongu et al., 2015). The human development index (HDI) represents a national average of achievements in three main aspects, namely: (i) knowledge, (ii) decent standards of living and (iii) long life and health. However, the IHDI goes beyond accounting for the national average to control for inequality in the distribution of these three accomplishments.

In accordance with recent African knowledge economy (KE) (Tchamyou, 2016) and mobile phone (Asongu \& Nwachukwu, 2016a) literature, the mobile phone indicator is proxied with the mobile phone penetration rate (per 100 people). Educational quality is measured with the 'pupil-teacher ratio' in primary education. There are three main motivations for the choice of this indicator. (i) We concerned about the degrees of freedom in the selection of other educational quality measurements (e.g. 'student-teacher ratio' in secondary or tertiary education), (ii) Relative to other educational levels, primary education has been shown to be more interconnected with positive externalities in economic development at the initial levels of industrialisation (see Stamatakis, 2002; Asiedu, 2014). These authors remarked that primary education is linked to more social returns relative to other educational levels when economies are at an early stage of industrialisation. (iii) Knowledge beyond primary education is not indispensable for the use of mobile phones. The choice of the 'pupil-teacher ratio' as the measurement of educational quality is consistent with recent literature (see Asongu \& Nwachukwu, 2016a). The study assumes that primary education is a basic and necessary condition for ICT literacy. Accordingly, the use of the mobile phone for inclusive human development purposes requires some elementary level of education. This is the intuition for modulating the use of mobile phone with education quality to affect inclusive human development.

Consistent with recent inclusive human development literature (Asongu \& Nwachukwu, 2016c), four control variables are considered, namely: GDP per capita, private domestic credit, foreign direct investment (FDI) and remittances. These variables have been substantially documented in the inclusive growth/development literature to exert a positive impact on inclusiveness (see Mlachila et al., 2014; Seneviratne \& Sun, 2013; Anand et al., 2012; Mishra et al., 2011). As emphasised by Ssozi and Asongu (2016), remittances are anticipated to enhance inclusive human development because, for the most part, they are used 
for consumption purposes. GDP per capita, credit facilities and FDI have been documented by Mlachila et al. (2014) as determinants of inclusive growth.

The definition of variables and corresponding sources are provided in Appendix 1, the summary statistics are disclosed in Appendix 2, while the correlation matrix is presented in Appendix 3.

\subsection{Methodology}

The Fixed Effects (FE) model is adopted in order to control for country-specific features or the unobserved heterogeneity. Moreover, when a panel consists of observations on fixed and comparatively small sets of cross section units (e.g. member states of a given region or specific fundamental characteristics), there is a presumption in favour of FE (see Asongu, 2016).

The issue of endogeneity (e.g. simultaneity) is tackled by employing an Instrumental Variable FE (IVFE) procedure. The instrumentation procedure for mobile phones and educational quality are respectively in $\mathrm{Eq}(1)$ and $\mathrm{Eq}(2)$ below.

$M o b_{i, t}=\alpha+\delta_{j}\left(M o b_{i, t-1}\right)+\varepsilon_{i, t}$,

where $M_{o b} b_{i, t}$, is the mobile phone indicator of country $i$ at period $t, \alpha$ is a constant, $M o b_{i, t-1}$, represents mobile phone in country $i$ at period $t-1$ and $\varepsilon_{i, t}$ the error term.

$E d u_{i, t}=\alpha+\delta_{j}\left(E d u_{i, t-1}\right)+\varepsilon_{i, t}$,

where $E d u_{i, t}$, is the educational indicator of country $i$ at period $t, \alpha$ is a constant, $E d u_{i, t-1}$, represents the educational indicator of country $i$ at period $t-1$ and $\varepsilon_{i, t}$ the error term. The procedure of instrumentation in Eq (1) consists of regressing the mobile phone on its first lags. The corresponding fitted values are then saved and later used as the independent variable of interest in Eq (3). The specifications are Heteroscedasticity and Autocorrelation Consistent (HAC) in standard errors.

The panel FE model is presented as follows:

$I H D_{i, t}=\partial_{0}+\partial_{1} M_{i, t}+\partial_{2} E_{i, t}+\partial_{3} M E_{i, t}+\sum_{h=1}^{4} \omega_{h} W_{h, i, t-\tau}+\eta_{i}+\varepsilon_{i, t}$

where $I H D_{i, t}$ is inclusive human development for country $i$ at period $t ; \partial$ is a constant; $M$, is mobile phone penetration; $E$, is educational quality ; $M E$, interaction between mobile phone penetration and educational quality; $W$ is the vector of control variables (GDP per 
capita growth, Private domestic credit, Remittances and Foreign direct investment); $\eta_{i}$ is the country-specific effect and $\varepsilon_{i, t}$ the error term.

Since, we are employing an estimation technique that deals with interactive regressions, it is important to briefly discuss some pitfalls linked to interactive specifications. According to Brambor et al. (2006), all constitutive indicators should be integrated into the specifications. Moreover, in order for the estimated parameters to make economic sense, they should be interpreted as conditional marginal impacts. Thresholds from which the modifying educational policy variable can complement mobile phones to have a positive effect on inclusive human development should be within the range provided by the summary statistics.

\section{Empirical results}

\subsection{Presentation of results}

The empirical findings for FE regressions are presented in Table 1. While the lefthand-side presents baseline regressions, the right-hand-side discloses more robust or instrumental variable regressions. The findings are discussed in terms of marginal effects, net impacts and threshold effects.

First, positive marginal effects are consistent across specifications. This is an indication that increasing human development results from the interactions between mobile phones and educational quality.

Second, the net effects based on conditional and unconditional effects are positive in the third specifications of the left-hand-side and right-hand-side regressions. For instance the net effect from education in the third specification in the left-hand-side is $0.0005([0.00002 \times$ $43.601]+[-0.0003])$ and in the right-hand-side is $0.0008([0.00003 \times 43.673]+[-0.0005])$. Accordingly, 43.601 and 43.673 are respectively the mean values of educational quality and instrumental educational quality (see Appendix 2).

Third, the corresponding thresholds are also within the range provided by the summary statistics (see Appendix 2). Accordingly, 15 (0.0003/0.00002) and 16.666 $(0.0005 / 0.00003)$ are the respective critically masses of educational quality and instrumental educational quality at which primary schooling complements mobile phones to start exerting a positive effect on inclusive human development. 


\begin{tabular}{|c|c|c|c|c|c|c|}
\hline \multirow[b]{3}{*}{ Constant } & \multicolumn{6}{|c|}{ Dependent Variable: Inequality Adjusted Human Development (IHDI) } \\
\hline & \multicolumn{3}{|c|}{$\begin{array}{c}\text { Baseline Regressions (Dependent Variable: } \\
\text { Quality of Education) }\end{array}$} & \multicolumn{3}{|c|}{$\begin{array}{c}\text { Instrumental Regressions (Dependent Variable: } \\
\text { Quality of Education) }\end{array}$} \\
\hline & $\begin{array}{l}0.428 * * * \\
(0.000)\end{array}$ & $\begin{array}{l}0.429 * * * \\
(0.000)\end{array}$ & $\begin{array}{l}0.439 * * * \\
(0.000)\end{array}$ & $\begin{array}{l}0.430 * * * \\
(0.000)\end{array}$ & $\begin{array}{l}0.442 * * * \\
(0.000)\end{array}$ & $\begin{array}{l}0.445 * * * \\
(0.000)\end{array}$ \\
\hline Mobile phones (Mob) & $\begin{array}{l}-0.000004 \\
(0.979)\end{array}$ & $\begin{array}{l}-0.00005 \\
(0.754)\end{array}$ & $\begin{array}{l}-0.0003 * \\
(0.067)\end{array}$ & --- & --- & --- \\
\hline Mobile phones (Mob)(IV) & --- & --- & --- & $\begin{array}{l}-0.00008 \\
(0.571)\end{array}$ & $\begin{array}{l}-0.0001 \\
(0.318)\end{array}$ & $\begin{array}{l}-0.0005^{* * *} \\
(0.002)\end{array}$ \\
\hline Education & $\begin{array}{l}-0.000009 \\
(0.968)\end{array}$ & $\begin{array}{l}-0.0001 \\
(0.457)\end{array}$ & $\begin{array}{l}-0.0004 \\
(0.125)\end{array}$ & --- & --- & --- \\
\hline Education(IV) & --- & --- & --- & $\begin{array}{l}0.00002 \\
(0.923)\end{array}$ & $\begin{array}{l}0.00001 * * * \\
(0.000)\end{array}$ & $\begin{array}{l}-0.0004 \\
(0.155)\end{array}$ \\
\hline Education.Mob & $\begin{array}{l}\text { 0.00001*** } \\
(\mathbf{0 . 0 0 0 )}\end{array}$ & $\begin{array}{l}\mathbf{0 . 0 0 0 0 1 * * *} \\
(\mathbf{0 . 0 0 0 )}\end{array}$ & $\begin{array}{l}0.00002 * * * \\
(0.000)\end{array}$ & --- & --- & --- \\
\hline Education (IV).Mob(IV) & -- & --- & --- & $\begin{array}{l}0.00002 * * * \\
(0.000)\end{array}$ & $\begin{array}{l}0.00001 * * * \\
(\mathbf{0 . 0 0 0 )}\end{array}$ & $\begin{array}{l}0.00003 * * * \\
(0.000)\end{array}$ \\
\hline GDP per capita growth & --- & $\begin{array}{l}0.0007 * * * \\
(0.004)\end{array}$ & $\begin{array}{l}0.0009 * * * \\
(0.002)\end{array}$ & --- & $\begin{array}{l}0.00004 \\
(0.893)\end{array}$ & $\begin{array}{l}0.0001 \\
(0.715)\end{array}$ \\
\hline Private Credit & --- & $\begin{array}{l}0.0005^{*} \\
(0.087)\end{array}$ & $\begin{array}{l}0.0006 * \\
(0.074)\end{array}$ & --- & $\begin{array}{l}0.0005 \\
(0.100)\end{array}$ & $\begin{array}{l}0.0007 * * \\
(0.049)\end{array}$ \\
\hline Remittances & --- & -- & $\begin{array}{l}0.0006 * * \\
(0.046)\end{array}$ & --- & -- & $\begin{array}{l}0.0004 \\
(0.184)\end{array}$ \\
\hline FDI & --- & --- & $\begin{array}{l}\text { 0.0003* } \\
(0.072)\end{array}$ & --- & --- & $\begin{array}{l}0.0001 \\
(0.586)\end{array}$ \\
\hline Thresholds & n.a & n.a & 15.00 & n.a & n.a & 16.666 \\
\hline Net Effects & n.a & n.a & 0.0005 & n.a & n.a & 0.0008 \\
\hline $\mathrm{R}^{2}$ (within) & 0.478 & 0.330 & 0.561 & 0.479 & 0.482 & 0.569 \\
\hline Fisher & $90.23 * * *$ & $54.50 * * *$ & $42.54 * * *$ & $74.90 * * *$ & $42.36 * * *$ & $36.29 * * *$ \\
\hline Countries & 44 & 43 & 38 & 40 & 38 & 34 \\
\hline Observations & 342 & 323 & 278 & 287 & 270 & 233 \\
\hline
\end{tabular}

*,**,***: significance levels of $10 \%, 5 \%$ and $1 \%$ respectively. STJA: Scientific and Technical Journal Articles. GDP: Gross Domestic Product. FDI: Foreign Direct Investment. na: thresholds and/or net effects cannot be computed because of insignificant marginal effects. The small conditional and unconditional effects do not matter much in the establishment of thresholds if both the numerator and denominator needed for the computation of the thresholds are small. Accordingly, the established thresholds make economic sense when they are within the range (minimum to maximum) disclosed by the summary statistics. Hence, what matters is that the established threshold should make economic sense.

It is important to articulate the context of threshold or critical mass. The notion of threshold is in accordance with Cummins (2000) on the minimum requirement of proficiency in a given language before a second language can be learned effectively. Furthermore, the definition of threshold in this study is also in line with the critical mass theory that has been considerably documented in the literature on economic development (see Roller \& Waverman, 2001; Ashraf \& Galor, 2013). A recent empirical application of the threshold or critical theory with interaction variables can be found in Batuo (2015). Therefore, from the perspective of this study, threshold impacts can be derived from interactive regressions. In the light of these clarifications, our conception and definition of threshold is consistent with: (i) critical mass for positive impacts (Roller \& Waverman, 2001; Batuo, 2015); (ii) conditions for 
Kuznets and U-shapes (Ashraf \& Galor, 2013) and (iii) minimum requirements for enjoying positive effects (Cummins, 2000).

The fact that the computed critical masses are within the lower limits of ranges (minimum to maximum) means that below-average education is needed to start enjoying the positive effect of mobile phone penetration on inclusive human development. In essence, an educational critical mass of 15 is close to the minimum in the range of 12.466 to 100.236 while an instrumented educational critical mass of 16.666 is also close to the minimum range of 12.978 to 98.978 . Hence, 10 and 27 pupils per teacher is needed in primary schools in order for mobile phones to enhance inclusive human development.

Fourth, all significant control variables have expected positive signs.

\subsection{Extensions based on fundamental characteristics}

In order to create opportunities for more policy implications, we decompose the dataset into fundamental features of human development based on political stability, religious domination, openness to sea, resource wealth, income levels and legal origins. The literature has documented these factors as important in human development (see Mlachila et al., 2014; Asongu, 2017b). An interesting literature by Mlachila et al. (2014, p.13) on the linkages between inclusive development recognised the following fundamental features: resourcewealth, state fragility, regional proximity and income levels. In line with the authors, inclusive human development is positively associated with political stability, income levels and resource-poor countries around the world because of the following reasons.

(1) It is more likely that high income nations are linked with better institutions to permit the equitable distribution of wealth accruing from economic prosperity. There are two main justifications for this positive linkage. On the one hand, higher incomes are associated with more opportunities for employment and social mobility. On the other hand, better institutions that are more related to higher income countries have been accepted to be critical in determining the quality of growth in Africa (Fosu, 2015b, 2015c).

(2) Countries with relatively more political stability are reasonably more likely to create conditions that are sympathetic for the benefits of economic growth to trickle down to less privileged factions of society.

(3) Consistent with the discourse on income levels above, whereas the likelihood that inclusive development is relatively better in resource-wealthy countries could run counter to intuition, there are also valid reasons for which to postulate that countries which have 
acknowledged scarcity in natural resources have focused more on knowledge economy and human capability development as means to achieve inclusive development and growth (Amavillah, 2015; Fosu, 2013; America, 2013). The narrative on human capability development aligns with the Kuada (2015) paradigm shift to 'soft economics' as means to understand Africa's non-inclusive development. (4) Legal origins have been shown to be fundamental in comparative contemporary economic development (see. La Porta et al., 1998, 1999). Agbor (2015) confirmed this assertion in recent African development literature. According to Beck et al. (2003), because of differences in political and adaptability mechanisms between French Civil law and English Common law countries, the latter have more 'enabling conditions' for the reduction of economic vulnerability and enhancement of social mobility. Accordingly, the French Civil law lays more emphasis on the state power compared to English common law countries which operate more on private property rights. It follows that the institutional web of enforcement features, informal norms and formal rules logically affect cross-country economic vulnerability and social mobility. (5) The foundation of religious domination is consolidated by the notion that inclusiveness is affected by solidarity. Islam and Christianity are the two such dominant religious models of solidity in Africa.

(6) Landlockedness has an institutional cost (see Arvis et al., 2007). Furthermore, such institutional drawbacks could be associated with less economic governance and/or the formulation and implementation of effective policies that deliver public commodities for inclusive development.

The criteria used to select the aforementioned fundamental country characteristics in items 2 to 6 immediately above are in line with recent inclusive development (Mlachila et al., 2014, p.13) and African development (Asongu, 2014a, p. 339) literature. In principle, the categorisation of legal origins is from La Porta et al (2008, p. 289) whereas the classification of income is in conformity with Asongu (2014b, p. 364) ${ }^{6}$ and the various World Bank publications. Resource-rich nations are based exclusively on oil-dominated exports that represent a substantial part of the GDP for at least a decade during the sampled periodicity. While landlocked versus coastal nations are directly apparent from an African map, the religious domination classification is from the Central Intelligence Agency (CIA) World Fact

\footnotetext{
${ }^{6}$ There are four main World Bank income groups: (i) high income, $\$ 12,276$ or more; (ii) upper middle income, $\$ 3,976-\$ 12,275$; (iii) lower middle income, $\$ 1,006-\$ 3,975$ and (iv) low income, $\$ 1,005$ or less.
} 
Book (CIA, 2011). Politically unstable nations are those that have experienced political violence/ instability during at least half of the investigated period.

In order to account for the underlying fundamental characteristics, a further analysis is performed on the relationship between educational quality, mobile phones and inclusive human development. Table 2 presents the corresponding findings based on each of the selected fundamental features of human development. While Panel A discloses baseline regressions, Panel B shows instrumental regressions. For lack of space, we report the independent variables of interest only given that most of the significant control variables display the expected signs.

The following findings can be established from Table 2. (1) On average terms, the threshold of educational quality for which mobile phones positively affect inclusive human development is between 10 and 26.66. This implies that between 10 and 27 pupils per teacher is needed in primary education, in order for educational externalities to materialise as inclusive human development following an increase in mobile phone penetration. (2) On the expected results, we find that: (i) English Common law countries enjoy higher net effects compared to their French Civil law counterparts, (ii) positive net effects are more apparent in politically stable (vis-à-vis politically unstable) countries and (iii) positive net impacts are also more noticeable in resource-poor (vis-à-vis resource-rich) countries. (3) With regard to unexpected findings: (i) low income (vis-à-vis higher income) countries have a higher net effect on inclusive development and (ii) landlocked (vis-à-vis coastal) countries experience higher net effects. (4) For the fundamental characteristic for which we could not anticipate a comparative advantage in inclusive development, Islam-dominated countries have a slightly higher net effect compared to their Christian-oriented counterparts.

We devote space to explaining the unexpected findings, particularly the superiority of low income and landlocked countries. One the one hand, countries that are landlocked could also acknowledge scarcity in logistic and transport facilities and therefore invest more in the knowledge economy for inclusive human development. This is the case with Rwanda for example. On the other hand, low income countries are more likely to harness inclusive development advantages associated with the mobile phone compared to higher income countries. For instance, low income countries are likely to benefit more from the use of mobile telephony for banking activities. This is consistent with evidence that the mobile phone has transformed the lives of many Africans by providing not just a means of communication, but also phone-based financial access to a previously unbanked/poor faction 
of the population (Jonathan \& Camilo, 2008; Demombynes \& Thegeya, 2012; Asongu, 2015). An example with which to support this perspective is a recent World Bank study which has revealed that Somalia, a low income country, is in the driver's seat when it comes to using the mobile phone for mobile banking services (see Mosheni-Cheraghlou, 2013). 


\begin{tabular}{|c|c|c|c|c|c|c|c|c|c|c|c|c|c|c|}
\hline & \multicolumn{14}{|c|}{ Panel A: Baseline Regressions (Dependent Variable: Quality of Education) } \\
\hline & \multicolumn{4}{|c|}{ Income Levels } & \multicolumn{2}{|c|}{ Legal Origins } & \multicolumn{2}{|c|}{ Religious Domination } & \multicolumn{2}{|c|}{ Openness to Sea } & \multicolumn{2}{|c|}{ Resource-Wealth } & \multicolumn{2}{|c|}{ Conflict } \\
\hline & UM. Income & M. Income & LM Income & L Income & English & French & Christian & Islam & Landlocked & Not Landlocked & Oil & Non-Oil & Conflict & Non Conflict \\
\hline Constant & $\begin{array}{l}0.309 * * * \\
(0.000)\end{array}$ & $\begin{array}{l}0.415 * * * \\
(0.000)\end{array}$ & $\begin{array}{l}0.452^{* * * *} \\
(0.000)\end{array}$ & $\begin{array}{l}0.461 * * * \\
(0.000)\end{array}$ & $\begin{array}{l}0.399 * * * \\
(0.000)\end{array}$ & $\begin{array}{l}0.453 * * * \\
(0.000)\end{array}$ & $\begin{array}{l}0.454 * * * \\
(0.000)\end{array}$ & $\begin{array}{l}0.446 * * * \\
(0.000)\end{array}$ & $\begin{array}{l}0.425 * * * \\
(0.000)\end{array}$ & $\begin{array}{l}0.433^{* * * *} \\
(\mathbf{0 . 0 0 0 )}\end{array}$ & $\begin{array}{l}0.428 * * * \\
(0.000)\end{array}$ & $\begin{array}{l}0.464 * * * \\
(0.000)\end{array}$ & $\begin{array}{l}0.311 * * * \\
(0.000)\end{array}$ & $\begin{array}{l}0.448 * * * \\
(0.000)\end{array}$ \\
\hline Mobile phones (Mob) & $\begin{array}{l}0.00009 \\
(0.869)\end{array}$ & $\begin{array}{l}0.00004 \\
(0.859)\end{array}$ & $\begin{array}{l}-0.00002 \\
(0.905)\end{array}$ & $\begin{array}{l}-0.0002 \\
(0.351)\end{array}$ & $\begin{array}{l}-0.0006 \text { *** } \\
(0.034)\end{array}$ & $\begin{array}{l}-0.0001 \\
(0.422)\end{array}$ & $\begin{array}{l}-0.0005 * * \\
(0.035)\end{array}$ & $\begin{array}{l}-0.0002 \\
(0.263)\end{array}$ & $\begin{array}{l}-0.001 * * * \\
(0.003)\end{array}$ & $\begin{array}{l}0.0001 \\
(0.547)\end{array}$ & $\begin{array}{l}-0.0005 \\
(0.626)\end{array}$ & $\begin{array}{l}-0.0003 * \\
(0.075)\end{array}$ & $\begin{array}{l}0.001 \\
(0.127)\end{array}$ & $\begin{array}{l}-0.0004 * * \\
(0.022)\end{array}$ \\
\hline Education & $\begin{array}{l}0.0008 \\
(0.546)\end{array}$ & $\begin{array}{l}-0.0002 \\
(0.592)\end{array}$ & $\begin{array}{l}0.0006 * \\
(0.073)\end{array}$ & $\begin{array}{l}-0.0007 * * \\
(0.028)\end{array}$ & $\begin{array}{l}-0.00005 \\
(0.908)\end{array}$ & $\begin{array}{l}-0.0003 \\
(0.300)\end{array}$ & $\begin{array}{l}-0.001 * * * \\
(0.003)\end{array}$ & $\begin{array}{l}0.0003 \\
(0.545)\end{array}$ & $\begin{array}{l}-0.001 * \\
(0.063)\end{array}$ & $\begin{array}{l}-0.00009 \\
(0.725)\end{array}$ & $\begin{array}{l}0.0004 \\
(0.170)\end{array}$ & $\begin{array}{l}-0.001 * * * * \\
(0.003)\end{array}$ & $\begin{array}{l}0.001 * * * \\
(0.006)\end{array}$ & $\begin{array}{l}-0.0005^{* * *} \\
(0.055)\end{array}$ \\
\hline Education.Mob & $\begin{array}{l}0.00001 \\
(0.527)\end{array}$ & $\begin{array}{l}0.00005 \\
(0.481)\end{array}$ & $\begin{array}{l}0.000007 \\
(0.192)\end{array}$ & $\begin{array}{l}0.00002^{* * * *} \\
(0.000)\end{array}$ & $\begin{array}{l}0.00004 * * * \\
(0.000)\end{array}$ & $\begin{array}{l}0.00001 * * * \\
(0.003)\end{array}$ & $\begin{array}{l}0.00002 * * * \\
(0.000)\end{array}$ & $\begin{array}{l}0.00003 * * * \\
(0.000)\end{array}$ & $\begin{array}{l}0.00005^{* * * *} \\
(0.000)\end{array}$ & $\begin{array}{l}0.000009 * \\
(0.052)\end{array}$ & $\begin{array}{l}0.00002 \\
(0.394)\end{array}$ & $\begin{array}{l}0.00002^{* * * *} \\
(0.000)\end{array}$ & $\begin{array}{l}-0.00003 \\
(0.192)\end{array}$ & $\begin{array}{l}0.00002 * * * \\
(0.000)\end{array}$ \\
\hline Control Variables & Yes & Yes & Yes & Yes & Yes & Yes & Yes & Yes & Yes & Yes & Yes & Yes & Yes & Yes \\
\hline Thresholds & na & na & na & 10 & 15 & 10 & 25 & 6.66 & 20 & 11.11 & na & 15 & na & 20 \\
\hline Net Effects & na & na & na & 0.00067 & 0.00114 & 0.00033 & 0.00067 & 0.00110 & 0.00118 & 0.00029 & na & 0.00057 & na & 0.00047 \\
\hline $\mathrm{R}^{2}$ (within) & 0.618 & 0.478 & 0.497 & 0.670 & 0.706 & 0.494 & 0.541 & 0.723 & 0.777 & 0.503 & 0.514 & 0.599 & 0.553 & 0.615 \\
\hline Fisher & $9.04 * * *$ & $11.27 * * *$ & $5.66 * * *$ & $40.67 * * *$ & $37.51 * * *$ & $16.33 * * *$ & $27.68 * * * *$ & $23.22 * * * *$ & $34.44 * * *$ & $22.82 * * *$ & $4.08 * * *$ & $42.50 * * * *$ & $4.78^{* * * *}$ & $45.56 * * *$ \\
\hline Countries & 6 & 14 & 8 & 24 & 17 & 21 & 27 & 11 & 10 & 28 & 6 & 32 & 8 & 30 \\
\hline Observations & 52 & 107 & 55 & 171 & 133 & 145 & 198 & 80 & 86 & 192 & 40 & 238 & 42 & 236 \\
\hline
\end{tabular}

\begin{tabular}{|c|c|c|c|c|c|c|c|c|c|c|c|c|c|c|}
\hline & \multicolumn{14}{|c|}{ dent Variable: Quality of Education) } \\
\hline & \multicolumn{4}{|c|}{ Income Levels } & \multicolumn{2}{|c|}{ Legal Origins } & \multicolumn{2}{|c|}{ Religious Domination } & \multicolumn{2}{|c|}{ Openness to Sea } & \multicolumn{2}{|c|}{ Resource-Wealth } & \multicolumn{2}{|c|}{ Conflict } \\
\hline & UM. Income & M. Income & LM Income & L Income & English & French & Christian & Islam & Landlocked & Not Landlocked & Oil & Non-Oil & Conflict & Non Conflict \\
\hline Constant & $\begin{array}{l}0.211 * * \\
(0.012)\end{array}$ & $\begin{array}{l}0.386 * * * \\
(0.000)\end{array}$ & $\begin{array}{l}0.475 * * * \\
(0.000)\end{array}$ & $\begin{array}{l}0.469 * * * \\
(0.000)\end{array}$ & $\begin{array}{l}0.438 \text { **** } \\
(0.000)\end{array}$ & $\begin{array}{l}0.430 * * * \\
(0.000)\end{array}$ & $\begin{array}{l}0.454 * * * \\
(0.000)\end{array}$ & $\begin{array}{l}0.439 * * * \\
(0.000)\end{array}$ & $\begin{array}{l}0.499 * * * * \\
(0.000)\end{array}$ & $\begin{array}{l}0.428 * * * \\
(0.000)\end{array}$ & $\begin{array}{l}0.418^{* * * *} \\
(0.000)\end{array}$ & $\begin{array}{l}0.465 * * * * \\
(0.000)\end{array}$ & $\begin{array}{l}0.292 * * * \\
(0.000)\end{array}$ & $\begin{array}{l}0.462 * * * * \\
(0.000)\end{array}$ \\
\hline Mobile phones (Mob)(IV) & $\begin{array}{l}0.0002 \\
(0.664)\end{array}$ & $\begin{array}{l}-0.0001 \\
(0.574)\end{array}$ & $\begin{array}{l}-0.0004 * * \\
(0.042)\end{array}$ & $\begin{array}{l}-0.0008 * * \\
(0.013)\end{array}$ & $\begin{array}{l}-0.0008 * * \\
(0.034)\end{array}$ & $\begin{array}{l}-0.0002 \\
(0.252)\end{array}$ & $\begin{array}{l}-0.0006 * * \\
(0.034)\end{array}$ & $\begin{array}{l}-0.0005 * * * \\
(0.007)\end{array}$ & $\begin{array}{l}-0.001 * * * * \\
(0.007)\end{array}$ & $\begin{array}{l}-0.0001 \\
(0.241)\end{array}$ & $\begin{array}{l}-0.0004 \\
(0.543)\end{array}$ & $\begin{array}{l}-0.0005 * * * \\
(0.004)\end{array}$ & $\begin{array}{l}-0.002 \\
(0.228)\end{array}$ & $\begin{array}{l}-0.0005 * * * \\
(0.003)\end{array}$ \\
\hline Education (IV) & $\begin{array}{l}0.002 * \\
(0.073)\end{array}$ & $\begin{array}{l}0.0004 \\
(0.401)\end{array}$ & $\begin{array}{l}0.0006 * \\
(0.087)\end{array}$ & $\begin{array}{l}-0.0009 * * \\
(0.018)\end{array}$ & $\begin{array}{l}-0.0008 \\
(0.174)\end{array}$ & $\begin{array}{l}0.0002 \\
(0.473)\end{array}$ & $\begin{array}{l}-0.0009 * * \\
(0.023)\end{array}$ & $\begin{array}{l}0.0005 \\
(0.380)\end{array}$ & $\begin{array}{l}-0.002 * * * * \\
(0.007)\end{array}$ & $\begin{array}{l}0.0001 \\
(0.532)\end{array}$ & $\begin{array}{l}0.0004 \\
(0.205)\end{array}$ & $\begin{array}{l}-0.0008 \text { ** } \\
(0.015)\end{array}$ & $\begin{array}{l}0.001 * * \\
(0.035)\end{array}$ & $\begin{array}{l}-0.0007 * * \\
(0.020)\end{array}$ \\
\hline Education(IV).Mob(IV) & $\begin{array}{l}0.00001 \\
(0.478)\end{array}$ & $\begin{array}{l}\text { 0.00001* } \\
(0.084)\end{array}$ & $\begin{array}{l}0.00002 * * * \\
(0.001)\end{array}$ & $\begin{array}{l}0.00003 * * * \\
(\mathbf{0 . 0 0 0 )}\end{array}$ & $\begin{array}{l}0.00004^{* * *} \\
(0.000)\end{array}$ & $\begin{array}{l}0.00001 * * * \\
(0.000)\end{array}$ & $\begin{array}{l}\mathbf{0 . 0 0 0 0 3} 3^{* * *} \\
(\mathbf{0 . 0 0 0 )}\end{array}$ & $\begin{array}{l}\mathbf{0 . 0 0 0 0 3}^{* * *} \\
(\mathbf{0 . 0 0 0 )}\end{array}$ & $\begin{array}{l}0.00005 * * * \\
(0.000)\end{array}$ & $\begin{array}{l}0.00001 * * * \\
(0.000)\end{array}$ & $\begin{array}{l}0.00002 \\
(0.232)\end{array}$ & $\begin{array}{l}0.00003 * * * \\
(0.000)\end{array}$ & $\begin{array}{l}0.00007 \\
(0.132)\end{array}$ & $\begin{array}{l}0.00003^{* * * *} \\
(0.000)\end{array}$ \\
\hline Control Variables & Yes & Yes & Yes & Yes & Yes & Yes & Yes & Yes & Yes & Yes & Yes & Yes & Yes & Yes \\
\hline Thresholds & na & 10 & 20 & 26.66 & 20 & 20 & 20 & 16.66 & 20 & 10 & na & 16.66 & na & 16.66 \\
\hline Net Effects & na & 0.0003 & 0.0004 & 0.0005 & 0.0009 & 0.0002 & 0.0007 & 0.0008 & 0.0011 & 0.0003 & na & 0.0008 & na & 0.0008 \\
\hline $\mathrm{R}^{2}$ (within) & 0.701 & 0.590 & 0.601 & 0.622 & 0.632 & 0.616 & 0.558 & 0.692 & 0.754 & 0.583 & 0.689 & 0.586 & 0.664 & 0.599 \\
\hline Fisher & $11.06 * * *$ & $14.23^{* * * *}$ & $6.24 * * *$ & $27.32 * * *$ & $22.09 * * * *$ & $21.81 * * *$ & $24.16 * * *$ & $16.37 * * *$ & $23.66 * * *$ & $26.20 * * *$ & $6.65^{* * * *}$ & $33.29 * * * *$ & $5.37 * * * *$ & $35.42 * * *$ \\
\hline
\end{tabular}


$*, * *, * * *$ significance levels of $10 \%, 5 \%$ and $1 \%$ respectively.GDP: Gross Domestic Product. FDI: Foreign Direct Investment. na: thresholds and/or net effects cannot be computed because of insignificant marginal effects. UM Income: Upper Middle Income Countries. M. Income: Middle Income Countries. LM Income: Lower Middle Income Countries. L. Income: Low Income Countries. English: English Common Law Countries. French: French Civil Countries. Christian: Christian Dominated Countries. Islam Oriented Countries. Landlocked: Landlocked Countries. Not Landlocked: Not Landlocked Countries. Oil: Oil-exporting Countries. Non-Oil: Non-oil exporting Countries. Conflict: Conflict Affected Countries. Non Conflict: Non Conflict Affected Countries. IV: Instrumental Variables. The small conditional and unconditional effects do not matter much in the establishment of thresholds if both the numerator and denominator needed for the computation of the thresholds are small. Accordingly, the established thresholds make economic sense when they are within the range (minimum to maximum) disclosed by the summary statistics. Hence, what matters is that the established threshold should make economic sense. 


\section{Concluding implications and future research directions}

The study has investigated critical masses or thresholds of educational quality at which the diffusion of knowledge with mobile phones enhances inclusive human development. The empirical evidence is based on simultaneity-robust Fixed Effects regressions with data from 49 sub-Saharan African countries for the period 2000-2012. The following key findings have been established. On the results without fundamental country characteristics: (i) positive marginal effects are consistent across specifications, implying that increasing human development can be traced to the interactions between mobile phones and educational quality, (ii) net effects based on conditional and unconditional effects are positive and (iii) between 10 and 27 pupils per teacher is needed in primary education in order for mobile phones to enhance inclusive human development. These below-mean (or average) thresholds imply that with a minimum policy effort to raise educational quality, new information and communication technologies like mobile phones (and related applications) can be effectively harnessed to fight non-inclusive human development in the post-2015 sustainable development agenda.

The following are observable from the results with fundamental characteristics. (1) On average terms, between 10 and 27 pupils per teacher is needed in primary education in order to capitalise on the inclusive human development benefits of increases in phone penetration. (2) On the projected outcomes, we find that: (i) English Common law countries enjoy higher net effects compared to their French Civil law counterparts, (ii) positive net effects are more apparent in politically stable (vis-à-vis politically unstable) countries and (iii) that positive net impacts are also more apparent in resource-poor (vis-à-vis resource-rich) countries. (3) With regard to unexpected findings (i) low income (vis-à-vis higher income) countries have a higher net effect on inclusive development and (ii) landlocked (vis-à-vis coastal) countries experience higher net effects. (4) For the fundamental country characteristic for which we could not anticipate a comparative advantage in inclusive development, Islam-dominated countries have a slightly higher net effect compared to their Christian-oriented counterparts.

In the light of these findings, we have confirmed that education plays an important role in the diffusion of knowledge for inclusive human development. This is consistent with the literature that education contributes to the creation and diffusion of knowledge for inclusive human development (Dakhi \& de Clereq, 2007; Dunlap-Hinkler et al., 2010). The findings have also confirmed that the previously established correlation between mobile 
phones and inclusive development in Africa (see Asongu, 2015) can be extended to causality. It is relevant to note that the underlying study is based on cross-sectional data. More generally, the findings of this study have confirmed the evolving stream of literature on the inclusive benefits of mobile phones engaged in the introduction.

Given that a recent World Bank report has shown that extreme poverty has been decreasing in all regions of the world with the exception of SSA, in the post-2015 sustainable development agenda, governments of sampled countries would benefit from improving the quality of education and engaging 'knowledge economy'-driven policies in order to harness the inclusive human development benefits of mobile phone usage. Future studies can improve on the existing literature by investigating other mechanisms by which the mobile phone can improve inclusive development in the sub-region in the light of the other challenges of the Sustainable Development Goals. 


\section{Appendices}

Appendix 1: Definitions and sources of variables

\begin{tabular}{|c|c|c|c|}
\hline Variables & Signs & Definitions & Sources \\
\hline Inclusive development & IHDI & Inequality adjusted human development index & UNDP \\
\hline Mobile Phone & Mobile & Mobile phone subscriptions (per 100 people) & WDI \\
\hline Mobile Phone (IV) & Mobile (IV) & $\begin{array}{l}\text { Instrumented mobile phone subscriptions (per } 100 \\
\text { people) }\end{array}$ & $\begin{array}{l}\text { Author's } \\
\text { calculation }\end{array}$ \\
\hline Educational Quality & Educ & Pupil teacher ratio in primary education & WDI \\
\hline Educational Quality (IV) & Educ(IV) & Instrumented pupil teacher ratio in primary education & $\begin{array}{l}\text { Authors' } \\
\text { calculation }\end{array}$ \\
\hline GDP per capita & GDPpcg & GDP per capita growth rate & \\
\hline Private Credit & Credit & $\begin{array}{l}\text { Private credit by deposit banks and other financial } \\
\text { institutions ( } \% \text { of GDP) }\end{array}$ & WDI \\
\hline Remittances & Remit & Remittances inflows (\% of GDP) & WDI \\
\hline Foreign investment & FDI & Foreign direct investment net inflows ( $\%$ of GDP) & WDI \\
\hline
\end{tabular}

\section{Appendix 2: Summary statistics}

\begin{tabular}{llllll}
\hline & Mean & SD & Min & Max & Obs \\
\cline { 2 - 6 } Inequality Adj. Human Development & 0.721 & 3.505 & 0.129 & 0.768 & 485 \\
Mobile Phone Penetration & 23.379 & 28.004 & 0.000 & 147.202 & 572 \\
Mobile Phone Penetration(IV) & 25.313 & 28.144 & 2.705 & 156.082 & 522 \\
Educational Quality & 43.601 & 14.529 & 12.466 & 100.236 & 444 \\
Educational Quality(IV) & 43.673 & 14.227 & 12.978 & 98.512 & 365 \\
GDP per Capita growth & 2.198 & 5.987 & -49.761 & 58.363 & 608 \\
Private Domestic Credit & 18.551 & 22.472 & 0.550 & 149.78 & 507 \\
Remittances & 3.977 & 8.031 & 0.000 & 64.100 & 434 \\
Net Foreign Direct Investment Inflows & 5.332 & 8.737 & -6.043 & 91.007 & 603 \\
\hline
\end{tabular}

SD: Standard deviation. Min: Minimum. Max: Maximum. Obs: Observations. Adj: Adjusted.

Appendix 3: Correlation Matrix (Uniform sample size : 233)

\begin{tabular}{crrrrrrl}
\hline Edu & GDPpcg & Credit & \multicolumn{1}{c}{ Remit } & \multicolumn{1}{c}{ FDI } & \multicolumn{1}{c}{ Mobile } & \multicolumn{1}{c}{ IHDI } & \\
\hline \multirow{2}{*}{1.000} & 0.029 & -0.369 & -0.073 & -0.118 & -0.461 & -0.096 & Edu \\
& 1.000 & 0.014 & 0.035 & 0.131 & -0.003 & -0.023 & GDPpcg \\
& & 1.000 & -0.096 & -0.117 & 0.471 & 0.599 & Credit \\
& & & 1.000 & 0.078 & -0.058 & -0.050 & Remit \\
& & & & 1.000 & 0.114 & -0.026 & FDI \\
& & & & & 1.000 & 0.049 & Mobile \\
& & & & & & 1.000 & IHDI
\end{tabular}

Edu : Educational quality. STJA: Scientific \& Technical Journal Articles. Internet: Internet Penetration. GDPpcg : GDP per capita growth rate. Credit: Private domestic credit. Remit: Remittances. FDI: Foreign Direct Investment. Mobile: Mobile Phone Penetration. IHDI: Inequality Adjusted Human Development Index. Ind. Vble:

Independent Variable. Dep. Vble: Dependent Variable. 


\section{References}

Abramowitz, M. (1986). "Catching-up, forging ahead or falling behind”, Journal of Economic History, 46(2), pp. 385-406.

Afutu-Kotey, R. L., Gough, K. W., \& Owusu, G., (2017). "Young Entrepreneurs in the Mobile Telephony Sector in Ghana: From Necessities to Aspirations", Journal of African Business, DOI: 10.1080/15228916.2017.1339252.

Agbor, J. A. (2015). "How does colonial origin matter for economic performance in subSaharan Africa?", In Augustin K. Fosu (Ed.), Growth and Institutions in African Development, Chapter 13, pp. 309-327, Routledge Studies in Development Economics: New York.

Aker, J. C., \& Fafchamps, M. (2010). How Does Mobile Phone Coverage Affect Farm-Gate Prices? Evidence from West Africa, Department of Economics and the Fletcher School, Tufts University.

Alkemade, F., \& Surrs, R. A. A., (2012). "Patterns of expectations for emerging sustainable technologies”, Technological Forecasting \& Social Change, 79(3), pp. 448-456.

Al Surikhi, H. F., (2012). "Knowledge and Financial Management in Households: An Examination of Married Women's Perspectives in Chadbourn, North Carolina", Capstone Collection, Paper No. 2489, Brattleboro.

Amankwah-Amoah, J., (2015). "Solar energy in sub-Saharan Africa: The challenges and opportunities of technological leapfrogging". Thunderbird International Business Review, 57(1), pp. 15-31.

Amankwah-Amoah, J., (2016). "Global business and emerging economies: Towards a new perspective on the effects of e-waste". Technological Forecasting and Social Change, 105 (April), pp. 20-26.

Amankwah-Amoah, J., \& Sarpong, D., (2016). "Historical pathways to a green economy: The evolution and scaling-up of solar PV in Ghana, 1980-2010". Technological Forecasting and Social Change, 102(January), pp. 90-101.

Amavilah, V. H. (2015). "Social Obstacles to Technology, Technological Change, and the Economic Growth of African Countries: Some Anecdotal Evidence from Economic History", MPRA Paper No. 63273, Munich.

America, R. (2013). "Economic Development with Limited Supplies of Management. What to do about it - the case of Africa", Challenge, 56(1), 61-71.

Anand, R., Mishra, S., \& Spatafora, N., (2012). "Structural Transformation and the Sophistication of Production," IMF Working Paper No. 12/59, Washington.

Arvis, J-F., Marteau, J-F., \& Raballand, G. (2007). "The cost of being landlocked: logistics costs and supply chain reliability”, Word Bank Working Paper Series No. 4258, Washington. 
Ashraf, Q., \& Galor, O., (2013). "The Out of Africa Hypothesis, Human Genetic Diversity, and Comparative Economic Development". American Economic Review, 103(1), pp. 1-46.

Asiedu, E., (2014). "Does Foreign Aid in Education Promote Economic Growth? Evidence From Sub-Saharan Africa", Journal of African Development, 16(1), pp. 37-59.

Asongu, S. A., (2014a). "African development: beyond income convergence", South African Journal of Economics, 82(3), pp. 334-353.

Asongu, S. A., (2014b). "Globalisation (fighting) corruption and development. How are these phenomena linearly and non-linearly related in wealth effects?", Journal of Economic Studies, 41(3), pp. 346-369.

Asongu, S. A., (2015). "The impact of mobile phone penetration on African inequality", International Journal of Social Economics, 42(8), pp. 706 -716.

Asongu, S. A., (2017a). "Conditional Determinants of Mobile Phones Penetration and Mobile Banking in Sub-Saharan Africa", Journal of the Knowledge Economy.

DOI: $10.1007 \% 2 F s 13132-015-0322-z$.

Asongu, S. A. (2017b). "Knowledge Economy Gaps, Policy Syndromes and Catch-Up Strategies: Fresh South Korean Lessons to Africa", Journal of the Knowledge Economy, 8(1), pp. 211-253.

Asongu, S. A., (2016). "Drivers of Growth in Fast Developing Countries: Evidence from Bundling and Unbundling Institutions", Politics \& Policy, 44(1), pp. 97-134.

Asongu, S. A., Boateng, A., \& Akamavi, R., (2016). "Mobile Phone Innovation and Inclusive Human Development: Evidence from Sub-Saharan Africa", African Governance and Development Institute Working Paper No. 16/027, Yaoundé.

Asongu, S. A., \& De Moor, L., (2015). "Recent advances in finance for inclusive development: a survey", African Governance and Development Institute Working Paper No. 15/005, Yaoundé.

Asongu, S. A., Efobi, U., \& Beecroft, I., (2015). "Inclusive Human Development in Pre-Crisis Times of Globalisation-Driven Debts", African Development Review, 27(4), pp. 428-442.

Asongu, S. A., \& Kodila-Tedika, O., (2017). "Is Poverty in the African DNA (Gene)?", South African Journal of Economics. DOI: 10.1111/saje.12165.

Asongu, S. A., \& Le Roux, S., (2017). "Enhancing ICT for inclusive human development in Sub-Saharan Africa", Technological Forecasting and Social Change, 118(May), pp. 44-54.

Asongu, S. A, \& Nwachukwu, J. C., (2016a). "The Mobile Phone in the Diffusion of Knowledge for Institutional Quality in Sub Saharan Africa", World Development, 86(October), pp. 133-147. 
Asongu, S. A., \& Nwachukwu, J. C., (2016b). "Mobile Phone Penetration, Mobile Banking and Inclusive Development in Africa", African Finance Journal, 18(1), pp. 34-52.

Asongu, S. A., \& Nwachukwu, J. C., (2016c). "The Role of Governance in Mobile Phones for Inclusive Human Development in Sub-Saharan Africa", Technovation, 55-56 (SeptemberOctober), pp. 1-13.

Asongu, S. A., \& Nwachukwu, J. C., (2017). "PhD by publication as an argument for innovation and technology transfer: With emphasis on Africa", Higher Education Quarterly. DOI: DOI: 10.1111/hequ.12141.

Asongu, S. A., Nwachukwu, J. C., \& Orim, S-M., I., (2017). "Mobile phones, institutional quality and entrepreneurship in Sub-Saharan Africa", Technological Forecasting and Social Change. DOI: 10.1016/j.techfore.2017.08.007.

Batuo, M. E., (2015). "The Role of Telecommunications Infrastructure In The Regional Economic Growth of Africa", The Journal of Development Areas, 49(1), pp. 313-330.

Becheikh, N., (2013). "The Impact of Knowledge Acquisition and Absorptive Capacity on Technological Innovations in Developing Countries: Evidence From Egyptian Small and Medium-Sized Enterprises”, Journal of African Business, 14(3), pp. 127-140.

Beck, T., Demirguiç-Kunt, A., \& Levine, R. (2003). "Law and finance: why does legal origin matter?", Journal of Comparative Economics, 31(4), pp. 653-675.

Bernard, A., \& Jones, C. (1996). "Technology and convergence”, The Economic Journal, 106 (437), pp. 1037-1044.

Best, M.H., (2015). "Greater Boston's industrial ecosystem: a manufactory of sectors". Technovation, 39-40 (2015), pp. 4-13.

Brambor, T., Clark, W. M., \& Golder, M., (2006). "Understanding Interaction Models:Improving Empirical Analyses”, Political Analysis, 14(1), pp. 63-82.

Brouwer, R., \& Brito, L., (2012). "Cellular phones in Mozambique: Who has them and who doesn't?”, Technological Forecasting \& Social Change, 79(2), pp. 231-243.

Chan, A., \& Jia, T., (2011). "The Role of Mobile Banking in Facilitating Rural Finance: Reducing Inequality in Financial Services between Urban and Rural Areas", Accenture Banking Services, http://www.accenture.com/SiteCollectionDocuments/PDF/PoV-MobileBanking-051611-EN.pdf (Accessed: 17/03/2015).

CIA (2011). Central Intelligence Agency, The World Factbook 2011.

Coleman, J.S. (1988). "Social capital in the creation of human capital", American Journal of Sociology, 94, (1998), pp. S95-S120.

Cozzens, S. E., (2011). "Editor's introduction: Distributional consequences of emerging technologies”, Technological Forecasting \& Social Change, 79 (2012), pp. 199-203. 
Cummins, J. (2000). Language, power and pedagogy: Bilingual children in the crossfire. Clevedon, England: Multilingual Matters.

Dakhi, M., \& de Clereq, D. (2007). "Human capital, social capital, and innovation: A multicountry study”, Entrepreneurship and Regional Development, 16(2), pp. 107-128.

Demombynes, G., \& Thegeya, A. (2012, March). "Kenya's Mobile Revolution and the Promise of Mobile Savings". World Bank Policy Research Working Paper, No. 5988, Washington.

Dunlap-Hinkler, D., Kotabe, M., \& Mudambi, R. (2010). "A story of break thorough versus incremental innovation: Corporate entrepreneurship in the global pharmaceutical industry", Strategic Entreneurship Journal, 4(2), pp. 106-127.

Fosu, A. (2013). Achieving development success: Strategies and lessons from the developing world, UNU-WIDER Policy Brief (November), Helsinki.

Fosu, A. K., (2015a). "Growth, Inequality and Poverty in Sub-Saharan Africa: Recent Progress in a Global Context”, Oxford Development Studies, 43(1), pp. 44-59.

Fosu, A. (2015b). Growth and Institutions in African Development, First edited by Augustin K. Fosu, , Routledge Studies in Development Economics: New York.

Fosu, A. (2015c). Growth and institutions in African Development, In A. K. Fosu (Ed.), Growth and Institutions in African Development, Chapter 1, pp. 1-17, Routledge Studies in Development Economics: New York.

Gupta, R., \& Jain, K., (2012). "Diffusion of mobile telephony in India: An empirical study", Technological Forecasting \& Social Change, 79(4), pp. 709-715.

Gupta, R., \& Jain, K., (2014). “Adoption of Mobile Telephony in Rural India: An Empirical Study”, Decision Sciences, 45(2), pp. 281-307.

Gupta, R., \& Jain, K., (2015). “Adoption behavior of rural India for mobile telephony: A multigroup study”, Telecommunications Policy, 39(8), pp. 691-704.

Hang, C.C., Garnsey, E., \& Ruan, Y., (2015). “Opportunities for disruption”. Technovation 39-40 (2015), pp. 83-93.

Hashim, N., (2014). "How Knowledge, Policy Planning, and Implementation Succeed or Fail: The Jatropha Projects in Tanzania”, Journal of African Business, 14(3), pp. 169-183.

Howells, J. (2005). "Innovation and Regional Economic development: A matter of perspective”, Research Policy, 34(8), pp. 1220-1234.

Ika, L., \& Saint-Macary, J., (2014). "Special Issue: Why Do Projects Fail in Africa?", Journal of African Business, 14(3), pp. 151-155. 
Islama, T., \& Meadeb, N., (2012). "The impact of competition, and economic globalization on the multinational diffusion of $3 \mathrm{G}$ mobile phones", Technological Forecasting \& Social Change, 79(5), pp. 843-850.

Jeong, Y., \& Yoon, B., (2015). "Development of patent roadmap based on technology roadmap by analyzing patterns of patent development". Technovation, 39-40 (2015), pp. 37-52.

Jin, J., \& von Zedtwitz, M., (2008). “Technological capability development in China's mobile phone industry”, Technovation, 28(6), pp. 327-334.

Jonathan, D., \& Camilo, T. (2008). "Mobile banking and economic development: Linking adoption, impact and use". Asian Journal of Communication, 18(4), pp. 318-322.

Joseph, N., Erasmus, W., \& Marnewick, C., (2014). "The Idle State of Information and Communication Technology Project Management", Journal of African Business, 14(3), pp. 184-196.

Kamukama, N., (2013). "Intellectual Capital: Firms' Hidden Source of Service Quality in the Microfinance Industry in Uganda”, Journal of African Business, 14(3), pp. 150-161.

Kirui, O. K., Okello, J. J., Nyikal, R. A., \& Njiraini, G. W., (2013). "Impact of Mobile PhoneBased Money Transfer Services in Agriculture: Evidence from Kenya", Quaterly Journal of International Agriculture, 52(2), pp. 141-162.

Kliner, M., Knight, A., Mamvura, C., Wright, J., \& Walley, J., (2013). "Using no-cost mobile phone reminders to improve attendance for HIV test results: a pilot study in rural Swaziland", Infectious Diseases of poverty, 2(12), pp. 1-7.

Kohlbacher, F., Herstatt, C., \& Levsen, N., (2015). "Golden opportunities for silver innovation: how demographic changes give rise to entrepreneurial opportunities to meet the needs of older people". Technovation 39-40 (2015), pp. 73-82.

Kumar, S., \& Zahn, C., (2003). "Mobile communications: evolution and impact on business operations", Technovation, 23(6), pp. 515-520.

Kuada, J. (2015). Private Enterprise-Led Economic Development, In J. Kuada (Ed.), SubSaharan Africa The Human Side of Growth, Palgrave Macmillan: New York.

Kuoa, Y-F., \& Yub, C-W., (2006). "3G telecommunication operators' challenges and roles: A perspective of mobile commerce value chain”, Technovation, 26(12), pp. 1347-1356.

Kwan, L.Y-Y, \& Chiu, C-Y (2015). "Country variations in diiferent innovation outputs: The interactive effect of institutional support and human capital", Journal of Organisational Behavior, 36(7), pp. 1050-1070.

La Porta, R., Lopez-de-Silanes, F., Shleifer, A., \& Vishny, R. W. (1998). "Law and finance", Journal of Political Economy, 106(6), pp.1113-1155. 
La Porta, R., Lopez-de-Silanes, F., Shleifer, A., \& Vishny, R. W. (1999). "The quality of government”, Journal of Law, Economics and Organization, 15(1), pp.222-279.

La Porta, R., Lopez-de-Silanes, F., \& Shleifer, A., (2008), "The Economic Consequences of Legal Origin," Journal of Economic Literature, 46(2), pp. 285-332.

Lee, M., Kim, K \& Cho, Y., (2010). "A study on the relationship between technology diffusion and new product diffusion", Technological Forecasting and Social Change, 77(5), 796-802.

Maine, E., Soh, P.-H., \& Dos Santos, N., (2015). "The role of entrepreneurial decision making in opportunity creation and recognition”. Technovation, 39-40(2015), pp. 53-72.

Makanyeza, C., \& Dzvuke, G., (2015). "The influence of innovation on the performance of small and medium enterprises in Zimbabwe", Journal of African Business, 15(1-2), pp. 198214.

Maurer, B. (2008, May). Retail electronic payments systems for value transfers in the developing world. Department of Anthropology, University of California.

Mishra, V., \& Bisht, S. S., (2013). "Mobile banking in a developing economy: A customercentric model for policy formulation", Telecommunications Policy, 37(6-7), pp. 503-514.

Mishra, S., Gable, S. L., \& Anand, R., (2011), "Service Export Sophsitication and Economic Growth,” World Bank Policy Working Paper No. 5606, Washington.

Mira, M., \& Dangersfield, B., (2012). "Propagating a digital divide: Diffusion of mobile telecommunication services in Pakistan”, Technological Forecasting \& Social Change, 79(3), pp. 448-456.

Mlachila, M., Tapsoba, R., \& Tapsoba, S. J. A., (2014). "A Quality of Growth Index for Developing Countries: A Proposal”, IMF Working Paper No. 14/172, Washington.

Mosheni-Cheraghlou, A., (2013). "Mobile Banking: Who is in the Driver's Seat?”, Working for a World Free of Poverty, The World Bank, http://blogs.worldbank.org/allaboutfinance/mobile-banking-who-driver-s-seat (Accessed: 19/03/2015)

Mpogole, H., Usanga, H., \& Tedre, M., (2008). "Mobile phones and poverty alleviation: a survey study in rural Tanzania", Proceedings of M4D 2008, Karlstad University, Sweden, pp. $62-72$.

Muto, M., \& Yamano, T., (2009). "The Impact of Mobile Phone Coverage Expansion on Market Participation: Panel Data Evidence from Uganda", World Development, 37(12), pp. 1887-1896.

Ofori, D., ( 2014). “An Exploratory Study of Project Management Competency in Ghana”, Journal of African Business, 14(3), pp. 197-210. 
Ojo, A., Janowski, T., \& Awotwi, J., (2012). "Enabling development through governance and mobile technology", Government Information Quarterly, 30 (2013), pp. S32-S45.

Ondiege, P., (2010). "Mobile Banking in Africa: Taking the Bank to the People", Africa Economic Brief, 1(8), pp. 1-16.

Overholm, H., (2015). "Collectively created opportunities in emerging ecosystems: the case of solar service ventures". Technovation, 39-40(2015), pp.14-25.

Penard, T., Poussing, N., Yebe, G. Z., \& Ella, P. N., (2012). "Comparing the Determinants of Internet and Cell Phone Use in Africa: Evidence from Gabon ", Communications \& Strategies, 86(2), pp. 65-83.

Petrakis, P. E., \& Stamatakis, D. (2002). "Growth and educational levels: a comparative analysis". Economics of Education Review, 21(2), pp. 513-521.

Qiang, C. Z., Kuek, S. C., Dymond, A., \& Esselaar, S., (2011). "Mobile Applications for Agricultural and Rural Development", ICT Sector Unit, World Bank http://siteresources.worldbank.org/INFORMATIONANDCOMMUNICATIONANDTECHN OLOGIES/Resources/MobileApplications_for_ARD.pdf (Accessed: 17/03/2015).

Ravallion, M., Chen, S., \& Sangraula, P., (2008). "Dollar a Day Revisited", World Bank Policy Research Working Paper No. 4620, Washington.

Roller, L-H., \& Waverman, L. (2001). "Telecommunications infrastructure and economic development: a simultaneous approach”, American Economic Review, 91(4), pp. 909-923.

Romer, P. M. (1990). “Endogenous technological change”, Journal of Political Economy, 98(5), pp. S71-S102.

Rosenberg, N. (1972). "Factors affecting the diffusion of technology", Explorations of Economic History, 10(1), pp. 3-33.

Sen, A. (2010). "The mobile and the world", Information Technologies and International Development, 6, pp.1-3.

Seneviratne, D., \& Sun, Y., (2013), "Infrastructure and Income Distribution in ASEAN-5: What are the Links?" IMF Working Paper No. 13/41, Washington.

Singh, A. B., (2012). "Mobile banking based money order for India Post: Feasible model and assessing demand potential”, Procedia - Social and Behavioral Sciences, 37(2012), pp. 466481.

Singh, A. B. (2012). "Mobile banking based money order for India Post: Feasible model and assessing demand potential", Procedia - Social and Behavioral Sciences, 37(2012), pp. 466481.

Solow, R. M. (1994). Perspectives on Economic growth theory", Journal of Economic Perspectives, 8(1), pp. 45-54. 
Sonne, L., (2012). "Innovative initiatives supporting inclusive innovation in India: Social business incubation and micro venture capital”, Technological Forecasting \& Social Change, 79(4), pp. 638-647.

Ssozi, J., \& Asongu, S. A., (2016). " The Effects of Remittances on Output per Worker in Sub-Saharan Africa: A Production Function Approach", South African Journal of Economics, 84(3), pp. 400-421.

Tarus, D. K., \& Sitienei, E. K. (2015). "Intellectual capital and innovativeness in software development firms: the moderating role of firm size", Journal of African Business, 15(1-2), pp. $48-65$.

Tchamyou, S. V., (2016). “The Role of Knowledge Economy in African Business", Journal of Knowledge Economy, DOI: 10.1007/s13132-016-0417-1.

Tchamyou, S. V., \& Asongu, S. A., (2017). "Information Sharing and Financial Sector Development in Africa", Journal of African Business, 18(1), pp. 24-49.

Thakar, D., (2012). "Market competition and the distributional consequences of mobile phones in Canada", Technological Forecasting \& Social Change, 79(2), pp. 223-230.

Wan, F., Williamson, P.J., \& Yin, E., (2015). “Antecedents and implications of disruptive innovation: evidence from China". Technovation, 39-40(2015), pp. 94-104.

World Bank (2015). "World Development Indicators", World Bank Publications http://www.gopa.de/fr/news/world-bank-release-world-development-indicators-2015 (Accessed: 25/04/2015).

Ureta, S. (2008). "Mobilising poverty?: Mobile phone use and everyday spatial mobility among low-income families in Santiago, Chile", Information Society, 24(2), pp. 83-92.

Uzawa, H. (1965). "Optimum technical change in an aggregative model of economic growth", International Economic Review, 6(1), pp. 17-31

Verspagen, B. (1992). "Uneven growth between interdependent economies: An evolutionary view on technology gaps, Trade and Growth", University of Limburg, Maastricht. 